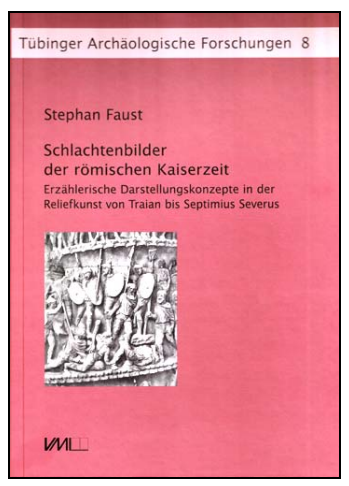

\section{Krzysztof Królczyk}

(Poznań)

\section{W KRĘGU RZYMSKICH RELIEFÓW BITEWNYCH}

Stephan Faust, Schlachtenbilder der römischen Kaiserzeit. Erzählerische Darstellungskonzepte in der Reliefkunst von Traian bis Septimius Severus, Tübinger Archäologische Forschungen 8, Verlag Marie Leidorf GmbH, Rahden/Westf. 2012,229 s.

Omawiana książka, poświęcona rzymskim wyobrażeniom bitewnym z okresu od Trajana do Septymiusza Sewera, jest zmienioną wersją dysertacji doktorskiej Stephana Fausta, która została napisana pod kierunkiem L. Giulianiego i obroniona w 2009 r. na Uniwersytecie Ludwika Maksymiliana w Monachium. Składa się ona z przedmowy (s. XIX), wprowadzenia (s. 1-7), trzech obszernych rozdziałów (s. 9-212), stanowiących zasadniczy rdzeń pracy, i zwięzłego podsumowania (s. 213-218). Niezwykle ważną częścią monografii są ilustracje przedstawiające omawiane na kartach książki monumenty (tabl. 1-81), zaś uzupełnieniem pracy jest wykaz skrótów bibliograficznych (s. XI-XVII), dalej indeksy: osobowy, geograficzny i rzeczowy (s. 219-225), wreszcie informacja o pochodzeniu ilustracji (s. 227-229).

We wprowadzeniu („Einleitung: Schlachtenbilder in der römischen Kaiserzeit”) Stephan Faust przedstawił główne zamierzenia swej pracy, tj. przeprowadzenie szczegółowej analizy warstwy narracyjnej wybranych rzymskich wyobrażeń bitewnych, oraz uzasadnił przyjęte przez siebie ramy chronologiczne. Dokonał ponadto omówienia stanu badań w interesującej go materii.

Pierwszy i zarazem najdłuższy z rozdziałów omawianej książki („Schlachtenbilder im Kontext stadtrömischen Staatsdenkmäler", s. 9-141; co ciekawe, oznaczony jest on rzymską cyfrą „II”, zaś cyfra „I” została przypisana do wprowadzenia) poświęcony został prezentacji przedstawień bitewnych w kontekście pomników państwowych wznoszonych w Rzymie. Przedmiotem analizy Autora w tej części pracy stał się najpierw tzw. wielki fryz Trajana (s. 9-30), który pierwotnie stanowił najprawdopodobniej element wyposażenia Forum Traiani. Jego fragmenty 
zostały w późniejszym okresie wtórnie umieszczone na łuku cesarza Konstantyna Wielkiego. S. Faust dokonał omówienia treści ikonograficznej zabytku, ze zwróceniem szczególnej uwagi na pojawiającą się dwukrotnie na nim postać Trajana, a następnie poczynił porównania scen z fryzu z wyobrażeniami bitewnymi znajdującymi się na brązowym kubku, odnalezionym ponoć w Rzymie w korycie Tybru (s. 30-34). Zdaniem Autora, pomimo pewnych podobieństw, dają się zauważyć zasadnicze różnice - o ile fryz przedstawiał wyimaginowaną scenę bitewną, w symboliczny sposób podkreślającą zwycięstwo Rzymian i Trajana nad Dakami, o tyle sceny batalistyczne z kubka są refleksem konkretnych wydarzeń historycznych, a mianowicie zdobycia dackiej stolicy - Sarmizegetusy.

W dalszej kolejności S. Faust zajął się omówieniem i szczegółową analizą spiralnego fryzu umieszczonego na kolumnie Trajana i przedstawiającego, jak powszechnie wiadomo, sceny bitewne $\mathrm{z}$ dwóch wojen dackich (s. 35-91). Analiza ta doprowadziła Autora do wniosku, że większość umieszczonych na kolumnie scen bitewnych powstała w oparciu o jedynie dwa schematycznie potraktowane wzorce kompozycyjne, wielokrotnie wmontowywane w kompozycje fryzu. Schemat A był związany z działaniami ofensywnymi prowadzonymi przez Rzymian, natomiast schemat B ukazywał kontrakcje Daków. S. Faust zwrócił ponadto uwagę czytelnika na fakt, że interpretacja fryzu z kolumny Trajana nie powinna być dokonywana wyłącznie w ujęciu horyzontalnym, jak się to najczęściej czyni, lecz także w ujęciu wertykalnym.

Logiczną kontynuacją wywodów o kolumnie Trajana stało się omówienie w dalszej części rozdziału spiralnego fryzu znajdującego się na kolumnie Marka Aureliusza, upamiętniającej zwycięstwa odniesione przez Rzymian w trakcie wojen z Markomanami i Sarmatami (s. 92-120). Zastosowano tu takie środki wyrazu jak ekspresyjność i redundancja, a ponadto niezwykle często ukazywano rzymskie akty przemocy, co było zapewne odpowiedzią na grozę wojen markomańskich. Koncepcja ideowa kolumny Marka Aureliusza zdecydowanie odróżniała się, zdaniem S. Fausta, od jej poprzedniczki z czasów Trajana. O ile ta ostatnia, poprzez zastosowanie wielokrotnie powtarzanych sekwencji bitewnych, w jakimś sensie oddawała koleje wojen dackich, o tyle kolumna cesarza Marka i jej reliefy ukazywały w całkowicie symboliczny sposób rzymską dominację nad światem barbarzyńskim, podobnie zresztą jak inne reliefy z czasów Marka Aureliusza, z których część została wtórnie umieszczona na łuku Konstantyna Wielkiego, a pozostała część jest przechowywana w Muzeach Kapitolińskich w Rzymie.

Jako ostatnie w tym rozdziale zostały omówione reliefy umieszczone po obu stronach znajdującego się na rzymskim Forum Romanum łuku Septymiusza 
Sewera, nazywanego przez Autora łukiem Sewerów (s. 121-141). Głosiły one chwałę oręża rzymskiego w wojnach zewnętrznych tego okresu, toczonych m.in. z Partami, oraz podkreślały wierność żołnierzy rzymskich wobec nowej dynastii (fides exercitus). Łuk Sewerów stanowił zarazem, w ujęciu S. Fausta, nie tylko świadectwo politycznej dominacji Septymiusza Sewera w Rzymie po zakończeniu wojen domowych, lecz również był dowodem konsensusu zawartego pomiędzy cesarzem a rzymską elitą senatorską.

Kolejny rozdział książki („Schlachtenbilder im Kontext provinzialer Ehrenmonumente”, s 143-175; nosi on rzymski numer „III”) został poświęcony analizie przedstawień bitewnych znajdujących się na pomnikach prowincjonalnych. Jako pierwszy omówienia doczekał się tzw. pomnik partyjski z Efezu (s. 143-167), dotąd powszechnie łączony z wyprawą partyjską cesarza Lucjusza Werusa. Stephan Faust zdołał jednak przekonująco wykazać, że relief ów, wbrew opinii wielu badaczy, powstał znacznie wcześniej, bo już w czasach Antoninusa Piusa, i przedstawiał alegoryczny obraz rządów tego władcy. Drugi z kolei scharakteryzowany został relief (s. 168-172) umieszczony pierwotnie na bramie o czterech wejściach (quadrifrons), wzniesionej ok. 205 r. po Chr. w Lepcis Magna, rodzinnym mieście Septymiusza Sewera. Widniejące na nim sceny bitewne nie służyły upamiętnieniu konkretnego zwycięstwa afrykańskiego cesarza, lecz były abstrakcyjnym wyobrażeniem cesarskich wiktorii. Rozdział ten zamyka porównanie reliefów z Lepcis Magna z fryzem z Kyreny (s. 172-175), również pochodzącym z czasów Sewera, będącym wyolbrzymioną wizją dokonań wojennych cesarza.

Trzeci i ostatni rozdział pracy („Schlachtsarkphage”, s. 177-212; nosi on rzymski numer „IV”) dotyczy analizy treści narracyjnych zawartych w wyobrażeniach ikonograficznych umieszczonych w kontekście sepulkralnym, tj. na sarkofagach. Przedmiotem zainteresowania Autora stały się wybrane sarkofagi pochodzące z miasta Rzymu, datowane przeważnie na lata $160-180$ po Chr. S. Faust wyróżnił tu dwie grupy zabytków: sarkofagi z przedstawieniami scen bitewnych, w których uczestniczyli Galowie (m. in. sarkofag z Vigna Ammendola), oraz sarkofagi zdobione scenami walk masowych (m.in. sarkofag $\mathrm{z}$ Portonaccio). Pojawienie się zabytków należących do pierwszej grupy, odwołujących się do wyobrażeń mitologicznych i przywołujących stereotyp Galla jako egzemplifikacji barbarzyńcy, miało swoje źródło - zdaniem S. Fausta - w wojnach toczonych przez Marka Aureliusza przeciw plemionom markomańskim i sarmackim. Z kolei powstanie drugiej grupy sarkofagów było zapewne, jak utrzymuje Autor omawianej publikacji, wyrazem istniejącej konkurencji pomiędzy przedstawicielami militarnej elity Cesarstwa Rzymskiego, skutkującej chęcią ukazania indywidualnych dokonań i statusu zmarłego. 
Omawiana książka, kierująca uwagę czytelnika na niezwykle ważne i przemawiające do wyobraźni odbiorcy (tak starożytnego, jak i współczesnego) elementy sztuki rzymskiej, jakimi bez wątpienia były sceny batalistyczne, stanowi niekwestionowane osiągnięcie jej Autora. Zdołał on na wybranych przykładach (zarówno rzymskich, jak i prowincjonalnych; tak państwowych, jak i prywatnych) przedstawić zasadnicze koncepcje narracyjne reliefów rzymskich w interesującym go okresie historycznym, a następnie ukazać ich linie rozwojowe i dokonujące się w nich, wraz z upływem lat, zmiany. Stephan Faust nie ograniczył się przy tym do powtórzenia już istniejących $\mathrm{w}$ nauce ustaleń, lecz pokusił się o dokonanie własnych interpretacji wybranych przez siebie dzieł rzymskiej sztuki, interpretacji - dodajmy - przekonujących. Reasumując, recenzowana książka z całą pewnością zajmie poczesne miejsce w literaturze przedmiotu, spotka się również - jak sądzę - z szerokim zainteresowaniem czytelników, tak specjalistów, jak i wszystkich miłośników starożytności, nie tylko w Niemczech, lecz również poza ich granicami. 